\title{
Erratum to: Multicentre randomized controlled trial comparing ferric(III) carboxymaltose infusion with oral iron supplementation in the treatment of preoperative anaemia in colorectal cancer patients
}

\author{
WAA Borstlap ${ }^{1 *}$, CJ Buskens ${ }^{1}$, KMAJ Tytgat ${ }^{2}$, JB Tuynman ${ }^{4}$, ECJ Consten ${ }^{5}$, RC Tolboom ${ }^{5}$, G. Heuff ${ }^{6}$, \\ AAW van Geloven ${ }^{7}$, BA van Wagensveld ${ }^{8}$, CACA Wientjes ${ }^{9}$, MF Gerhards ${ }^{10}$, SMM de Castro ${ }^{10}$, J. Jansen ${ }^{11}$, \\ AWH van der Ven ${ }^{12}$, E. van der Zaag ${ }^{13}, \mathrm{JM} \mathrm{Omloo}^{13}, \mathrm{HL}$ van Westreenen ${ }^{14}$, DC Winter ${ }^{15}$, RP Kennelly ${ }^{15}$, \\ MGW Dijkgraaf ${ }^{3}$, PJ Tanis ${ }^{1}$ and WA Bemelman ${ }^{1}$
}

Erratum to: BMC Surgery doi:10.1186/s12893-015-0065-6

Following publication of the original version of this article in BMC Surgery [1] it was brought to our attention that the name of one author was spelled incorrectly. The name of author A.A.W. van Geloven was incorrectly spelled as 'N. van Geloven'.

\footnotetext{
Author details

'Department of Surgery, Academic Medical Centre, University of Amsterdam, Amsterdam, The Netherlands. ${ }^{2}$ Department of Gastroenterology, Academic Medical Centre, University of Amsterdam, Amsterdam, The Netherlands. ${ }^{3}$ Clinical Research Unit, Academic Medical Centre, University of Amsterdam, Amsterdam, The Netherlands. ${ }^{4}$ Department of Surgery, VU University Medical Centre, Amsterdam, The Netherlands. ${ }^{5}$ Department of Surgery, Meander Medical Centre, Amersfoort, The Netherlands. ${ }^{6}$ Department of Surgery, Borstlap et al. BMC Surgery (2015) 15:78 Spaarne Hospital, Hoofddorp, The Netherlands. ${ }^{7}$ Department of Surgery, Tergooi Hospital, Hilversum, The Netherlands. ${ }^{8}$ Department of Surgery, Sint Lucas Andreas Hospital, Amsterdam, The Netherlands. ${ }^{9}$ Department of Gastroenterology, Sint Lucas Andreas Hospital, Amsterdam, The Netherlands. ${ }^{10}$ Department of Surgery, Onze Lieve Vrouwe Gasthuis, Amsterdam, The Netherlands. ${ }^{11}$ Department of Gastroenterology, Onze Lieve Vrouwe Gasthuis, Amsterdam, The Netherlands. ${ }^{12}$ Department of Surgery, Flevo Hospital, Almere, The Netherlands.

${ }^{13}$ Department of Surgery, Gelre Hospital, Apeldoorn, The Netherlands.

${ }^{14}$ Department of Surgery, Isala Hospital, Zwolle, The Netherlands.

${ }^{15}$ Department of Surgery, St. Vincent's Hospital, Dublin, Ireland.
}

Received: 7 September 2015 Accepted: 7 September 2015 Published online: 08 October 2015

\footnotetext{
* Correspondence: w.a.borstlap@amc.uva.nl

'Department of Surgery, Academic Medical Centre, University of Amsterdam,
} Amsterdam, The Netherlands

\section{Reference}

1. Borstlap WA et al. Multicentre randomized controlled trial comparing ferric(III)carboxymaltose infusion with oral iron supplementation in the treatment of preoperative anaemia in colorectal cancer patients. BMC Surgery. 2015;15:78.
Submit your next manuscript to BioMed Central and take full advantage of:

- Convenient online submission

- Thorough peer review

- No space constraints or color figure charges

- Immediate publication on acceptance

- Inclusion in PubMed, CAS, Scopus and Google Scholar

- Research which is freely available for redistribution 